\title{
Bats of Florida 1
}

\section{Ginger M. Allen and Martin B. Main²}

\section{Introduction}

Nocturnal (night time) habits, affinity for eerie places, and silent, darting flight have made bats the subjects of a great deal of folklore and superstition through the years. Able to function in the dark when and where humans cannot, it is no wonder that bats have been associated with the supernatural in the past. Bats remain poorly understood even today.

The general lack of understanding of bats has contributed to alarming declines in bat populations. Some of the more important causes of these declines include destruction of habitat, harmful pesticides, and disturbance of nesting colonies. Two species of Florida bats are listed as endangered at the federal level. These include the Gray bat (Myotis grisescens), and the Indiana bat (Myotis sodalis). The Florida Mastiff bat (Eumops glaucinus floridanus) is listed as an endangered species at the state level.

Bats are highly and uniquely adapted to catch night-flying insects. They use their wings, the skin around their tails, and their mouths to catch insects in flight. Most locate their food and navigate by uttering a continuous series of ultrasonic cries that return as echoes off solid objects. This form of navigation is termed echolocation. This technique is also used by dolphins to detect prey and navigate in conditions of low visibility.

Bats are the only mammals capable of true flight. They are in the taxonomic order Chiroptera, which means hand-wing. A bat's fore limbs have the same configuration as other mammals', but the bones of the fingers are elongated to support membranous wings. The hind limbs are also modified to allow them to alight and hang, head-down, by their toes.

Bats rest during daylight hours and take shelter in a variety of places: caves, mines, buildings, rock crevices, under tree bark, and amongst foliage. Many species congregate in nursery colonies during the spring and disperse in July and August when they begin their migration to hibernation sites (usually caves).

Most Eastern species produce one young per year; several species produce two, and one produces up to four. Colony female bats group together to make a nursery before they have their young. When all of the bats are crowded together, the temperature of the nursery is raised to more than 100 degrees $\mathrm{F}$. As these young bats have no fur, they need a warm

1. This document is Fact Sheet WEC 186, one of a series of the Department of Wildlife Ecology \& Conservation, Florida Cooperative Extension Service, Institute of Food and Agricultural Sciences, University of Florida. Publication date: October 2004. Please visit the Edis Web site at http://edis.ifas.ufl.edu.

2. Ginger M. Allen, senior biologist, and Martin B. Main, associate professor, wildlife extension specialist, Southwest Florida Research and Education Center, Immokalee, FL; Department of Wildlife Ecology and Conservation, Institute of Food and Agricultural Sciences, University of Florida, Gainesville, FL 32611-0304.

The Institute of Food and Agricultural Sciences (IFAS) is an Equal Employment Opportunity - Affirmative Action Employer authorized to provide research, educational information and other services only to individuals and institutions that function without regard to race, creed, color, religion, age, disability, sex, sexual orientation, marital status, national origin, political opinions or affiliations. For information on obtaining other extension publications, contact your county Cooperative Extension Service office. Florida Cooperative Extension Service / Institute of Food and Agricultural Sciences / University of Florida / Larry R. Arrington, Interim Dean 
and humid place to survive. Solitary or

foliage-roosting bats tend to have more than one young at a time. They often possess thicker and more colorful fur than colony-roosting bats. Like other mammals, young bats are fed on milk until they are capable of foraging on their own.

Most Indiana bats that summer in the American midwest migrate south (mainly to Kentucky) to spend the winter in large caves. It is critical that a hibernation site is cool with temperatures that remain above freezing and that it is relatively free of human disturbance. If a bat is aroused from hibernation too many times, it will decrease its fat reserves to a point where it cannot survive through the winter. Generally, bats do not feed during hibernation. Indiana bats hibernate in dense clusters, in some cases literally carpeting cave walls and ceilings. The hibernation clusters can contain up to 300 bats per square foot.

Bats are an important part of the natural system. They prey upon insects, some of which are agricultural or human pests. The Little Brown Bat (Myotis lucifugus) can eat up to 600 mosquitoes an hour. A group of 150 Big Brown Bats (Eptesicus fuscus) can consume 18 million rootworms each year. Bats also consume cutworm and corn borer moths, potato beetles, and grasshopper crop pests. Cave-dwelling bats contribute nutrient-rich guano (feces) that acts as a fertilizer which supports ground-dwelling cave life. Bats are important animals in scientific research, providing insights into hibernation and sonar mechanisms.

This document discusses representative species of the bats that occur in Florida and provides a simple key for their identification.

\section{Florida Bats}

There are 18 species representing 3 families of bats in Florida (Table 1). Twilight bats (family Vespertilionidae) are the best represented with 14 species. Free-tailed bats (family Molossidae) include three species. One species of leaf-nosed or New World fruit bats (family Phyllostomidae) occurs only in the Florida Keys.

Twilight and free-tailed bats that occur in eastern North America are insectivorous and can be divided into two groups: those that typically roost only in trees and those that spend at least a portion of the year in caves (Table 1). When caves and forests are scarce, bats may also roost in buildings, culverts, bridges, and hollow trees. Utilizing the key characteristics other than roosting preferences, as listed in the identification key, will help in identifying bats.

Tree roosting bats are typically solitary and roost under leaves, branches, or within tree cavities to blend into their surroundings. Free-tailed bats of Florida form roosting colonies in trees and buildings. The Brazilian free-tailed bat is the only free-tailed bat commonly found throughout the state. The Jamaican fruit bat also roosts in trees and is the only member of the New World fruit bats that occur in Florida.

Some Twilight bat colony species are entirely dependent upon caves (Gray bat). Historically, caves provided safe environments with stable temperatures ideal for bat colonies. Because cave roosting bats may congregate in large numbers (hundreds of thousands) and because suitable cave habitats for large colonies are limited in number, these species are extremely vulnerable to human disturbance. Human disturbance, such as caused by caving activities, panics bats and causes them to waste valuable energy, and may result in abandonment and mortality of young. Destruction of suitable cave habitat through commercialization, flooding by man-made reservoirs, and other causes has resulted in population declines to the point that several species face the threat of extinction. The six other Twilight bats that prefer cave roosting for their colonies will also roost in trees and/or buildings (Table 1.) Recognition of the need for cave conservation and protection of bat colonies (natural and urban) from human disturbance is critical for the continued survival of these fascinating animals.

\section{Identification of Florida Bats}

Some simple guidelines can help identify Florida bats. Free-tailed bats have naked tails that extend well beyond the wing edge; hairy feet; and narrow wings. Within this group, the Mastiff bats have faces that resemble snub-nosed dogs, hence the name. Florida Twilight bats do not have tails that extend past the wing membrane. Between the three groups of bats, there are more species of Twilight bats in Florida. 
However, most Floridians will encounter the colony-roosting bats, which tend to be darker in color, often brown, with no fur on the wing or tail membranes. Colony-roosting bats are the types of bats that people encounter most often because these bats are also adaptable to buildings (such as the Brazilian free-tailed bat). Florida's single fruit/leaf-nosed bat possesses a fleshy flap or noseleaf on the snout and large eyes that compensate for relatively poor echolocation abilities.

A simple key to the identification of Florida's 18 species of bats is provided below. The key is divided into bats that roost in caves (seven species) and bats that roost in trees (11 species). Consequently, information on roosting behavior is an important aid to the identification of Florida bats. Back fur color, root color (determined by experts blowing on and parting the back fur), shape of the fleshy part of the ear (the tragus), position of attachment of the tail membrane, and length and density of hairs on the toes are useful characters for identification. The fleshy keel on the calcar (a cartilaginous structure on the rear edge of the tail membrane - see Figure 1) is also a useful characteristic for distinguishing among similar-looking species.

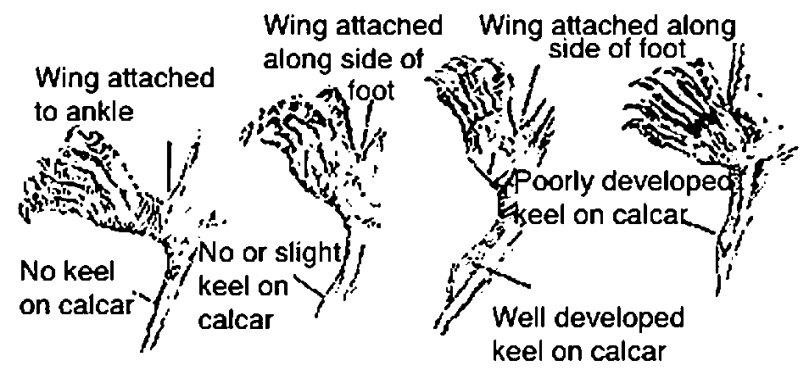

Figure 1. Diagram of bat wing attachment and calcar keel combinations. Used with permission from Missouri Conservation Commission.

\section{Identification Key to Florida Bats}

\section{Cave Roosting Bats}

A. Usually roosting in large colonies (hundreds or thousands)

1. Fur on back uniform gray; wing membrane attached to ankle; tragus narrow and pointed; guano piles under cave roosts; reddish-brown ceiling stains; bats usually not seen in winter

Gray bat (Myotis grisescens) ENDANGERED (Federal/State)

2. Fur on back brownish gray with dark roots; short gray ears; tragus short narrow and pointed; calcar keeled; no guano piles under roosts; bats usually not seen in winter

Indiana bat (Myotis sodalis) ENDANGERED (Federal/State)

3. Fur on back short; brownish gray with dark roots; short gray ears; tragus short narrow and pointed; calcar not keeled; usually produces more than one young; will roost in buildings

Southeastern bat (Myotis austroriparius)

B. Usually roosting singly or in very small clusters (fewer than 20)

1. Large size (total length 4" to 5"); fur on back dark brown; dark ears and membranes

Big Brown bat (Eptesicus fuscus)

2. Small size (total length less than 4")

a. Fur on back pale yellowish or pale reddish-brown

Eastern Pipistrelle bat (Pipistrellus subflavus)

b. Fur on back dark glossy brown

Ears long (about 3/4")

\author{
Northern Long-eared bat (Myotis \\ septentrionalis) \\ c. Ears shorter (usually 5/8" or less), ears/face \\ dark
}

\section{Little Brown bat (Myotis lucifugus)}

\section{Tree/Building Roosting Bats}

A. Usually roosting in large clusters (hundreds or thousands) 
1. Gray body $>5$ ", short funnel-like joined ears; narrow brown wings; extended tail; hairy toes with cleaning bristles

Florida Wagners Mastiff bat (Eumops glaucinus floridanus) -ENDANGERED (State)

2. Small body <5”, ears not obviously joined

a. Commonly found throughout Florida; 2 lower incisors

Brazilian Free-tailed bat (Tadarida brasiliensis)

b. Only found in the Florida Keys; one lower incisor

\section{Little Mastiff bat (Molossus molossus)}

B. Usually roosting singly in or in very small clusters (fewer than 20)

1. Tail does not extend past wing membrane; mouse eared bats; solitary roosters

a. Ears large, 1" long and joined; lump between the eyes

\section{Rafinesques Big-eared bat (Corynorhinus} rafinesquii)

b. Ears $<1$ " long

i. Body fur yellowish

Northern Yellow bat (Lasiurus intermedius)

ii. Body fur red

Red bat (Lasiurus borealis)

iii. Body fur mahogany

\section{Seminole bat (Lasiurus seminolus)}

iv. Body fur dark brown with white tips; wing span $>15$ "

\section{Hoary bat (Lasirus cinereus)}

v. Body fur dark brown with white tips; wing span <13"
Silver-haired bat (Lasionycteris noctivagans)

vi. Body fur short, sparse, dull brown

Evening bat (Nycticeius humeralis)

2. Lacking tail; nose with fleshy flap; fruit-eating; found in Florida Keys

Jamaican/Antillean Fruit Bat (Artibeus jamaicensis)

\section{Additional Information}

Brown, L.N. 1997. Mammals of Florida. Windward Publishing Inc., Miami, Florida.

Florida Bat Center. Available at http://www.floridabats.org/Index.htm.

Checklist of Florida's Mammals. 1999. Florida Fish and Wildlife Conservation Commission, Tallahassee, Florida.

Kern, W.H., Belwood, J.J., and P.G. Koehler. 1995. Bats in Buildings. University of Florida, IFAS Extension document ENY-268. Available at www.edis.ifas.ufl.edu.

Mazzotti, F.J. and L.A. Brandt. 2002. Bats of South Florida. University of Florida, IFAS Extension document WEC-10. Available at www.edis.ifas.ufl.edu.

Missouri Dept. of Conservation. Fact Sheet On Bats. 2003. Available at http://www.conservation.state.mo.us/nathis/mammals/ batfacts/index.htm.

Taylor, A.K., Mazzotti, F.J., and C.N. Huegel. 2002. Bats. Information for the Florida Homeowner. University of Florida, IFAS Extension document WEC-32. Available at http://www.edis.ifas.ufl.edu www.edis.ifas.ufl.edu.

Whitaker, J.O. Jr., 1998. Mammals of the Eastern United States, Cornell University Press, Ithaca, NY. 
Table 1. Florida bat species and ecological features

\begin{tabular}{|c|c|c|c|c|}
\hline Taxa & $\begin{array}{l}\text { Florida } \\
\text { Range }\end{array}$ & Abundance & $\begin{array}{c}\text { Roosting } \\
\text { Habitat }\end{array}$ & Comments \\
\hline \multicolumn{5}{|l|}{ Twilight Bats } \\
\hline $\begin{array}{l}\text { Big brown bat } \\
\text { (eptesicus fuscus) }\end{array}$ & $\begin{array}{l}\text { Statewide } \\
\text { except Keys }\end{array}$ & Rare & $\begin{array}{l}\text { Caves, trees, } \\
\text { buildings }\end{array}$ & Roost near entrance \\
\hline $\begin{array}{l}\text { Silver-haired bat } \\
\text { (Lasionycteris } \\
\text { noctivagans) }\end{array}$ & Panhandle & Rare & Trees & Migratory species \\
\hline $\begin{array}{l}\text { Red bat } \\
\text { (Lasiurus borealis) }\end{array}$ & Northern $1 / 2$ & Common & Trees & $\begin{array}{l}\text { Sexually dimorphic, } \\
\text { females less colorful }\end{array}$ \\
\hline $\begin{array}{l}\text { Hoary bat } \\
\text { (Lasiurus cinereus) }\end{array}$ & Northern $1 / 3$ & Uncommon & Trees & $\begin{array}{l}\text { Large bat, } \\
\text { white-tipped fur }\end{array}$ \\
\hline $\begin{array}{l}\text { Northern yellow bat } \\
\text { (Lasiurus intermedius) }\end{array}$ & $\begin{array}{l}\text { Statewide } \\
\text { except Keys }\end{array}$ & Common & Trees, palm fronds & $\begin{array}{l}\text { Very common in southern } \\
\text { Florida }\end{array}$ \\
\hline $\begin{array}{l}\text { Seminole bat } \\
\text { (Lasiurus seminolus) }\end{array}$ & $\begin{array}{l}\text { Statewide except } \\
\text { Keys }\end{array}$ & Common & $\begin{array}{l}\text { Trees, Spanish } \\
\text { moss }\end{array}$ & $\begin{array}{l}\text { Southeastern species named } \\
\text { for Seminole Indians }\end{array}$ \\
\hline $\begin{array}{l}\text { Southeastern bat } \\
\text { (Myotis austroriparius) }\end{array}$ & Northern 2/3 & Abundant & $\begin{array}{l}\text { Caves, trees, } \\
\text { buildings }\end{array}$ & $\begin{array}{l}\text { Large mixed-species maternity } \\
\text { colonies }\end{array}$ \\
\hline $\begin{array}{l}\text { Gray bat } \\
\text { (Myotis grisescens) }\end{array}$ & Panhandle & $\begin{array}{l}\text { Rare } \\
\text { Endangered }\end{array}$ & Caves, year-round & $\begin{array}{l}\text { Endangered by loss of cave } \\
\text { habitit }\end{array}$ \\
\hline $\begin{array}{l}\text { Little brown bat } \\
\text { (Myotis lucifugus) }\end{array}$ & Northern border & $\begin{array}{l}\text { Few } \\
\text { records }\end{array}$ & Caves, buildings & $\begin{array}{l}\text { Probably do not reproduce in } \\
\text { Florida }\end{array}$ \\
\hline $\begin{array}{l}\text { Northern long-eared bat } \\
\text { (myotis septentrionalis) }\end{array}$ & Panhandle & $\begin{array}{l}\text { Few records, } \\
\text { Endangered }\end{array}$ & $\begin{array}{l}\text { Caves, trees, } \\
\text { buildings }\end{array}$ & $\begin{array}{l}\text { Probably do not reproduce in } \\
\text { Florida }\end{array}$ \\
\hline $\begin{array}{l}\text { Indiana bat } \\
\text { (Myotis sodalis) }\end{array}$ & Panhandle & $\begin{array}{l}\text { Few records, } \\
\text { Endangered }\end{array}$ & Caves, trees & Summer migrant \\
\hline $\begin{array}{l}\text { Evening bat } \\
\text { (Nycticeius humeralis) }\end{array}$ & $\begin{array}{l}\text { Statewide } \\
\text { except Keys }\end{array}$ & Common & Trees, buildings & $\begin{array}{l}\text { Residents joined by } \\
\text { northern migrants }\end{array}$ \\
\hline $\begin{array}{l}\text { Eastern Pipistrelle bat } \\
\text { (Pipistrellus subflavus) }\end{array}$ & $\begin{array}{l}\text { Statewide } \\
\text { except Keys }\end{array}$ & Common & Caves, trees & Florida's smallest bat \\
\hline $\begin{array}{l}\text { Rafinessque's big-eared } \\
\text { bat } \\
\text { (Corynorhinus rafinesquii) }\end{array}$ & Northern 3/4 & Uncommon & Trees, buildings & Prefers cypress tree cavities \\
\hline \multicolumn{5}{|l|}{ Free-tailed Bats } \\
\hline $\begin{array}{l}\text { Florida wagner's mastiff } \\
\text { bat (Eumops glaucinus } \\
\text { floridanus) }\end{array}$ & Southern $1 / 4$ & $\begin{array}{l}\text { Rare: State } \\
\text { Endangered }\end{array}$ & $\begin{array}{l}\text { Tree hollows, } \\
\text { buildings }\end{array}$ & Florida's largest bat \\
\hline $\begin{array}{l}\text { Little mastiff bat } \\
\text { (Molossus molossus) }\end{array}$ & Keys & Rare & Buildings & Tropical species \\
\hline $\begin{array}{l}\text { Brazilian fee-tailed bat } \\
\text { (Tadarida brasiliensis) }\end{array}$ & $\begin{array}{l}\text { Statewide } \\
\text { except Keys }\end{array}$ & Common & Buildings, trees & Live in colonies year round \\
\hline \multicolumn{5}{|c|}{ New World Fruit/leaf-nosed Bats } \\
\hline $\begin{array}{l}\text { Jamaican fruit bat } \\
\text { (Artibeus jamaicensis) }\end{array}$ & Lower Keys & $\begin{array}{l}\text { Few } \\
\text { records }\end{array}$ & Trees & $\begin{array}{l}\text { Florida's only fruit } \\
\text { eater, prefers figs }\end{array}$ \\
\hline
\end{tabular}

